\title{
E-Payment System and Financial Performance of Telecom Companies in Rwanda: Case Study of MTN Rwanda MOMO Service
}

\author{
SHEMA Bertin* Dr. Jaya Shukla \\ School of Business and Economics, Mount Kenya University Rwanda, PO box 5826 Kigali, Rwanda
}

\begin{abstract}
The purpose of the study was to investigate the impact of e-payment system and financial performance of telecommunication companies and the study carried out in MTN Rwanda, MOMO service. E-payment system as independent variable and financial performance as dependent variable. This study has the following specific objectives: To examine the money transfer services on financial performance of MTN Rwanda; to evaluate the financial key performance indicators of MTN Rwanda; to investigate the e-payment services on the financial performance of MTN Rwanda; to assess the role of mobile banking on financial performance of MTN Rwanda between 2016 and 2019; and to establish the relationship between e-payment system and financial performance. The study shows findings shows that 31 (53.4\%) of Respondents strongly agreed that sending and receiving money between two subscribers of MOMO service highly affect profitability Ratio of MTN Rwanda. It Indicates that 26 (44.8\%) of Respondents strongly agreed that buying airtime with MOMO service affect an increase in Sales volume of MTN Rwanda. It indicates that 27 (46.6\%) of Respondents strongly agreed that paying TV with MOMO service positively affect long term investment of MTN Rwanda. It indicates that $32(55.2 \%)$ of Respondents strongly agreed that depositing and withdrawing money on bank account with MOMO service highly affect profitability Ratio. The findings prove that there is a positive correlation between money transfer services and long term investment $(\mathrm{p}=.774$ and $\mathrm{sig}=.000)$; between payment and profitability $(\mathrm{p}=.972$ and $\mathrm{sig}=.000)$; between mobile banking services and improved sales volume $(\mathrm{p}=.866 \mathrm{and}$ sig $=.000)$; between money transfer services and payment services ( $p=.785$ and sig $=.000$ ); between payment service and mobile banking services $(p=.781$ and sig $=.000)$; long term investment and profitability $(\mathrm{p}=.986$ and $\mathrm{sig}=.000$ ). Hence, the results indicate that e-payment systems have a positive and significant relationship with financial performance of MTN Rwanda MOMO services.
\end{abstract}

Keywords: E-payment, Money transfer, Mobile banking, Mobile money, financial performance

DOI: $10.7176 / \mathrm{JESD} / 11-16-18$

Publication date:August $31^{\text {st }} 2020$

\section{Introduction}

The history of E-payment can be traced back to 1918 the time when currency was first moved in the United States (US) by Federal Reserve Bank with the aid of telegraph. However, that technology had not been widely used in the US until the time when their Automated clearing house (ACH) was incorporated in 1972. Since that time, the electronic money turned out to be quite popular. This enabled U.S commercial banks and its central treasury came out with an alternative to cheque payment.(Ul et al., 2017). Traditionally, banks have always sought media through which they would serve their clients more cost-effectively as well as increase the utility of their clientele. Their main concern has been to serve clients more conveniently, and in the process increase profits and competitiveness. Electronic and communication technologies have been used extensively in banking for many years to advance the agenda for banking. (Nzaro \& Magidi, 2014). In recent years there has been considerable interest in the development of electronic money schemes. Electronic money has the potential to take over from cash as the primary means of making small-value payments and could make such transactions easier and cheaper for both consumers and merchants (Bank for International Settlements, 2000). In Rwanda, telecommunication industry becomes one of the sector which has the influence in Rwandan economy, one of the best telecommunication company we have today is MTN Rwanda which began its operations in 1990, starting out as an exclusive GSM network providing voice and SMS services. The portfolio has exponentially grown where MTN launched MTN mobile money in February 2010. Mobile money (MOMO) is a form of electronic money that allows you to conduct financial transaction using your mobile phone. It allows financial services to be extended to unbanked people at a significantly lower cost because physical infrastructure is not needed. The growth in mobile phone ownership raises the potential for mobile money to reach unbanked people, providing them with a more affordable payments system. Mobile money plays a role in e-payment system in Rwanda because is trusted because of its confidentiality, MOMO is easy to use, is fast transfer of money to the receiver, MOMO is convenience, affordability, acceptability and short/simple procedure to register for the service and no account maintenance fee for keeping money in the mobile phone. 


\subsection{Problem Statement}

Now days, government of Rwanda efforts digital payment systems in business services in order to facilitate business performance and rapid services to buyers and sellers. Rwanda's vision 2020 seeks to transform the economy from cash-based economy to a digital-driven economy, among other targets. To achieve this, the government and central bank have been at the fore of promoting technology among financial sector players and business community over the past few years. In addition, the national Bank of Rwanda has been conducting campaigns to promote use of digital financial services across all the sectors. According to central bank, the business community loses up to 6 per cent in non-electronic transactions compared to only 2 per cent if they used digital payment platforms. There has also been greater collaboration between telecom firms and the banks, a situation that is increasing fostering the growth of digital and mobile banking services (The New times, 2017). A telecom company like MTN Rwanda introduced mobile money electronic payment platform called MOMO service to help the mobile phone users to pay for goods and services, savings, to withdraw money on their bank account and to transfer money, it increase the quality of financial services and the cost of loan facilities, to access the financial services and also ensuring a consumer experience The inception of mobile money has changed how business is being done (Oloko, n.d.). It has made financial transactions to be easy and faster and at the same time provided a saving avenue for those without bank accounts. However, determining the success of the mobile money remains challenges considering that are becoming exposed to fraud related risks. Majority of studies have sought to establish the impact of mobile money on commercial Banks in Kenya. Mobile money affects banking services in commercial Banks but does not focus on the effect on the Telecom companies' performance. With all the studies that have been done to try and establish the effect of mobile money on financial performance focused on commercial Banks. Thus, this necessitated the current study conducted on the impact of mobile money on financial performance of Telecom companies in Rwanda.

\subsection{Objectives of Study}

This study has both general and specific objectives:

\subsubsection{General Objective}

The general objective of this study was to investigate the e-payment services on financial performance of telecom companies in Rwanda.

\subsubsection{Specific Objectives}

i. To examine the influence of mobile money transfer services on financial performance of MTN Rwanda.

ii. To investigate the mobile money payment services on financial performance of MTN Rwanda.

iii. To assess the role of mobile banking services on financial performance of MTN Rwanda.

iv. To evaluate the financial key performance indicators of MTN Rwanda.

\subsection{Research Questions}

i. Is there any relationship between money transfer service and financial performance of MTN Rwanda?

ii. Does e-payment service have an influence on financial performance of MTN Rwanda?

iii. Does mobile banking service have a role on financial performance of MTN Rwanda?

iv. What are the financial key performance indicators of MTN Rwanda?

\subsection{Conceptual Framework}

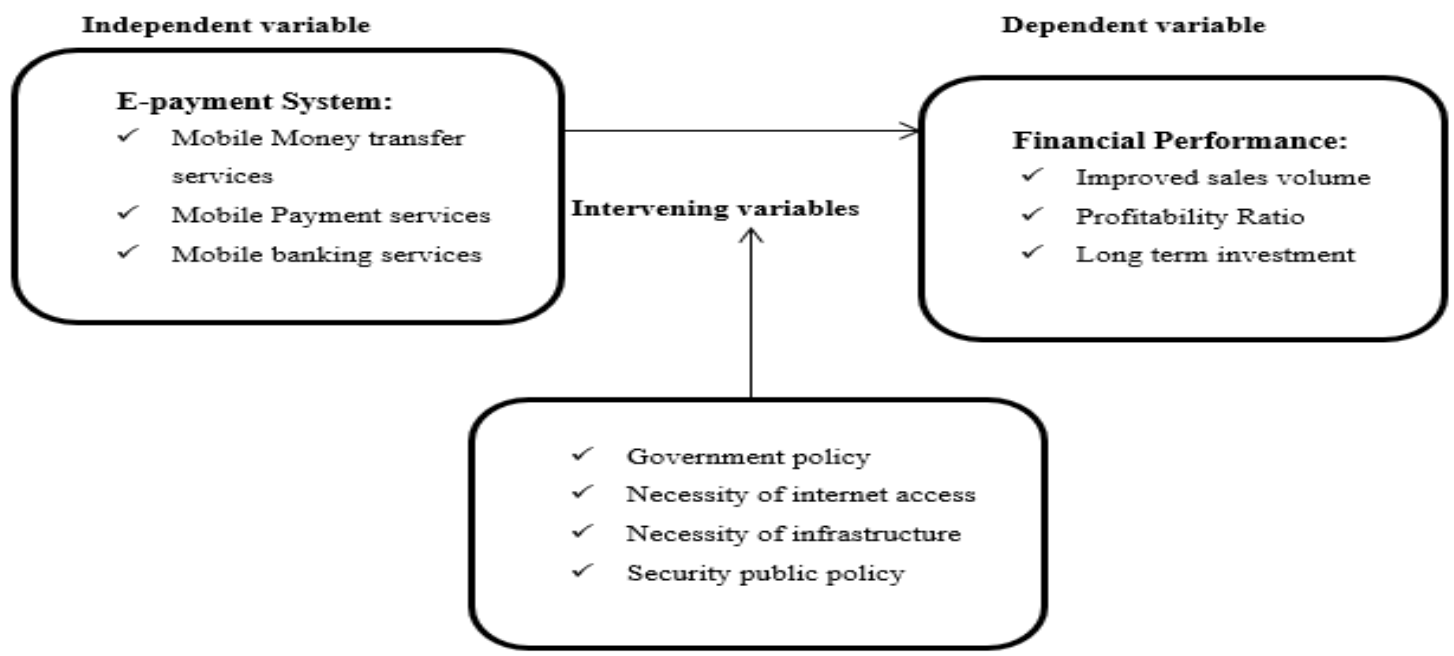




\section{Research Design}

In this study, the researcher used descriptive design with mean and standard deviation and correlation design to explore the contribution of electronic payment on financial performance of MTN Rwanda. Descriptive method was used to illustrate description of a population while correlational design was used to check if two or more variables are associated with each other.

\subsection{Target Population}

The target population for the study consisted of 58 employees from the department of finance, marketing and sales \&distribution of MTN Rwanda, in Gasabo District, Kigali City.

Table 1: Showing the target population

\begin{tabular}{lll}
\hline Strata & Populating & Sample Design \\
\hline Finance & 15 & Census \\
Marketing & 13 & Census \\
Sales \& Distribution & 30 & Census \\
Total & 58 & Census \\
\hline
\end{tabular}

Source: MTN Rwanda, 2019

\subsection{Sample Size}

Researcher took the entire population which is 58 staff working in the department of finance, marketing and sales \&distribution.

\subsubsection{Sampling Techniques}

In this study, the census sampling technique was used for selecting the 58 employees from the department of finance, marketing and sales \&distribution.

\subsection{Data Collection Methods}

Data were collected using questionnaires distributed to the respondents.

\subsubsection{Data Collection Instruments}

The primary data were collected from the respondents using questionnaires and documentary search.

\section{Research results and discussion}

\subsection{Presentation of the Findings}

\subsubsection{Components of e-payment system of telecom companies}

In this section, the researcher wanted to find out the Components of e-payment system of telecom companies as well as the financial key performance of MTN Rwanda. The researcher identified 3 components of e-payment system within MTN Rwanda such are mobile money transfer services, mobile money payment services and mobile banking services.

\subsubsection{Mobile money transfer services on financial performance of MTN Rwanda.}

This section is about the discussion and interpretation of the views of the respondents about Mobile money transfer services on financial performance of MTN Rwanda in order to achieve the first specific objective of the study. 
Table 2: Perceptions of respondents about where mobile money transfer services affect financial performance of MTN Rwanda

\begin{tabular}{|c|c|c|c|}
\hline & & Frequency $(n=58)$ & Percent \\
\hline & Strongly Agree & 31 & 53.4 \\
\hline \multicolumn{2}{|l|}{ Sending and receiving money between two subscribers of Agree } & 13 & 22.4 \\
\hline \multirow[t]{4}{*}{ MOMO affect profitability Ratio of MTN } & Undecided & 9 & 15.5 \\
\hline & Disagree & 3 & 5.2 \\
\hline & Strongly Disagree & 2 & 3.4 \\
\hline & Strongly Agree & 28 & 48.3 \\
\hline \multirow{5}{*}{$\begin{array}{l}\text { Sending and receiving money between two subscribers of } \\
\text { MOMO affect increase in sales volume }\end{array}$} & Agree & 14 & 24.1 \\
\hline & Undecided & 10 & 17.2 \\
\hline & Disagree & 1 & 1.7 \\
\hline & Strongly Disagree & 5 & 8.5 \\
\hline & Strongly Agree & 30 & 51.7 \\
\hline \multirow{4}{*}{$\begin{array}{l}\text { Sending and receiving money between two subscribers of } \\
\text { MOMO affect long term Investment }\end{array}$} & Agree & 13 & 22.4 \\
\hline & Undecided & 10 & 17.2 \\
\hline & Disagree & 2 & 3.4 \\
\hline & Strongly Disagree & 3 & 5.2 \\
\hline \multirow{5}{*}{$\begin{array}{l}\text { Sending and receiving money between subscriber and no } \\
\text { subscriber of MOMO affect profitability ratio }\end{array}$} & Strongly Agree & 28 & 48.3 \\
\hline & Agree & 16 & 27.6 \\
\hline & Undecided & 9 & 15.5 \\
\hline & Disagree & 3 & 5.2 \\
\hline & Strongly Disagree & 2 & 3.4 \\
\hline \multirow{5}{*}{$\begin{array}{l}\text { Sending and receiving money between subscriber and no } \\
\text { subscriber of MOMO affect increase in sale volume }\end{array}$} & Strongly Agree & 29 & 50.0 \\
\hline & Agree & 16 & 27.6 \\
\hline & Undecided & 8 & 13.8 \\
\hline & Disagree & 3 & 5.2 \\
\hline & Strongly Disagree & 2 & 3.4 \\
\hline \multirow{5}{*}{$\begin{array}{l}\text { Sending and receiving money between subscriber and no } \\
\text { subscriber of MOMO affect in long term investment }\end{array}$} & Strongly Agree & 27 & 46.6 \\
\hline & Agree & 16 & 27.6 \\
\hline & Undecided & 8 & 13.8 \\
\hline & Disagree & 2 & 3.4 \\
\hline & Strongly Disagree & 5 & 8.5 \\
\hline \multirow{5}{*}{ Sending money outside using MOMO affect profitability } & Strongly Agree & 32 & 55.2 \\
\hline & Agree & 16 & 27.6 \\
\hline & Undecided & 8 & 13.8 \\
\hline & Agree & 1 & 1.7 \\
\hline & Strongly Disagree & 1 & 1.7 \\
\hline \multirow{5}{*}{$\begin{array}{l}\text { Sending money outside using MOMO affect increase I sale } \\
\text { volume }\end{array}$} & Strongly Agree & 31 & 53.4 \\
\hline & Agree & 12 & 20.7 \\
\hline & Undecided & 8 & 13.8 \\
\hline & Disagree & 3 & 5.2 \\
\hline & Strongly Disagree & 4 & 6.9 \\
\hline \multirow{5}{*}{$\begin{array}{l}\text { Sending money outside using MOMO affect long-term } \\
\text { investment }\end{array}$} & Strongly Agree & 25 & 43.1 \\
\hline & Agree & 16 & 27.6 \\
\hline & Undecided & 8 & 13.8 \\
\hline & Disagree & 7 & 12.1 \\
\hline & Strongly Disagree & 2 & 3.4 \\
\hline
\end{tabular}

\section{Source: Primary Data, 2019}

Table 2 shows that $31(53.4 \%)$ of Respondents strongly agreed that sending and receiving money between two subscribers of MOMO service highly affect profitability Ratio of MTN Rwanda, 28 (48.3\%) of Respondents strongly agreed that sending and receiving money between two subscribers of MOMO service affect an increase in Sales Volume of MTN Rwanda, 30 (51.7\%) of Respondents strongly agreed that sending and receiving between 
a subscriber and non-subscriber of MOMO service highly affect profitability Ratio of MTN Rwanda, 36 (62.3\%) of Respondents strongly agreed that sending and receiving two subscribers positively affect a long term investment of MTN Rwanda, The same above table2. indicates that 28 (48.3\%) of Respondents strongly agreed that to Send Money Outside the Country affects Profitability of MTN Rwanda, 29 (50.0\%) of Respondents strongly agreed that on receiving money from outside the country on MOMO service highly affect profitability ratio of MTN Rwanda, $27(46.6 \%)$ of Respondents strongly agreed that sending and receiving money between a subscriber and nonsubscriber of MOMO service affect an increase in sales volume of MTN Rwanda, 32 (55.2\%) of Respondents strongly agreed that sending the money outside the country using MOMO service affect an increase in sales volume of MTN Rwanda. Thus, implies that mobile money transfer services affect financial performance of MTN Rwanda. 3.1.3 Mobile money payment on financial performance of MTN Rwanda

In this subsection, the researcher presents analyses and interprets the respondents' perceptions about the impact of mobile money payment services on financial performance of MTN Rwanda basing on the data collected using questionnaire and interview guide.

Table 3: perceptions of respondents about the impact of mobile money payment on financial performance of MTN Rwanda

\begin{tabular}{lll}
\hline & Frequency $(n=58)$ & Percent
\end{tabular}

Strongly Agree $\quad 26 \quad 44.8$

To buy airtime with MOMO affect profitability ratio

Agree 16

Undecided $\quad 8 \quad 13.8$

Disagree $\quad 5 \quad 8.6$

Strongly Disagree $\quad 3 \quad 5.2$

Strongly Agree $\quad 27 \quad 46.6$

Agree $\quad 16 \quad 27.6$

To buy airtime with MOMO affect increase in sale volume

Undecided

Disagree

Strongly Disagree $\quad 2 \quad 3.4$

Strongly Agree $\quad 27 \quad 46.6$

Agree $\quad 17 \quad 29.3$

To buy airtime with MOMO affect long term investment

Undecided

Disagree

Strongly Disagree $\quad 2 \quad 3.4$

$\begin{array}{lll}\text { Strongly Agree } & 23 & 39.7\end{array}$

$\begin{array}{lll}\text { Agree } & 19 & 32.8\end{array}$

To pay for electricity affect profitability ratio

Undecided $9 \quad 15.5$

Disagree $3 \quad 5.2$

Strongly Disagree $\quad 4 \quad 6.9$

Strongly Agree $\quad 26 \quad 44.8$

Agree $\quad 16 \quad 27.6$

To pay for electricity affect increase in sale volume

Undecide

Strongly Disagree $\quad 5 \quad 8.5$

Strongly Agree $\quad 26 \quad 44.8$

Agree $\quad 18 \quad 31.0$

To pay for electricity long term investment

Undecided

Disagree 
To pay TV with MOMO services affect increase in sales volume

To pay TV with MOMO services affect long term investment

\section{Postpaid bill payment affect profitability ratio}

Postpaid bill payment affect increase in sale volume

Postpaid bill payment affect long term investment

To pay school fees with MOMO services affect profitability ratio

To pay school fees with MOMO services affect increase in sale volume

To pay school fees with MOMO services long term investment

To pay for taxes affect profitability ratio

To pay for taxes affect increase in sale volume

\begin{tabular}{|c|c|c|}
\hline Strongly Agree & 32 & 55.2 \\
\hline Agree & 13 & 22.4 \\
\hline Undecided & 9 & 15.5 \\
\hline Disagree & 3 & 5.2 \\
\hline Strongly Disagree & 1 & 1.5 \\
\hline Strongly Agree & 29 & 50.0 \\
\hline Agree & 15 & 25.9 \\
\hline Undecided & 10 & 17.5 \\
\hline Disagree & 2 & 3.4 \\
\hline Strongly Disagree & 2 & 4.2 \\
\hline Strongly Agree & 30 & 51.7 \\
\hline Agree & 14 & 24.1 \\
\hline Undecided & 9 & 15.5 \\
\hline Disagree & 1 & 1.7 \\
\hline Strongly Disagree & 5 & 8.5 \\
\hline Strongly Agree & 29 & 50.0 \\
\hline Agree & 14 & 24.1 \\
\hline Undecided & 9 & 15.5 \\
\hline Disagree & 1 & 1.7 \\
\hline Strongly Disagree & 4 & 6.9 \\
\hline Strongly Agree & 28 & 48.3 \\
\hline Agree & 15 & 25.9 \\
\hline Undecided & 9 & 15.5 \\
\hline Disagree & 2 & 3.4 \\
\hline Strongly Disagree & 3 & 5.2 \\
\hline Strongly Agree & 28 & 48.3 \\
\hline Agree & 15 & 25.9 \\
\hline Undecided & 9 & 15.5 \\
\hline Disagree & 1 & 1.7 \\
\hline Strongly Disagree & 5 & 8.5 \\
\hline Strongly Agree & 29 & 50.0 \\
\hline Agree & 15 & 25.9 \\
\hline Undecided & 9 & 15.5 \\
\hline Disagree & 2 & 3.4 \\
\hline Strongly Disagree & 4 & 6.9 \\
\hline Strongly Agree & 30 & 51.7 \\
\hline Agree & 13 & 22.4 \\
\hline Undecided & 9 & 15.5 \\
\hline Disagree & 3 & 5.2 \\
\hline Strongly Disagree & 3 & 5.2 \\
\hline Strongly Agree & 31 & 53.4 \\
\hline Agree & 14 & 24.1 \\
\hline Undecided & 9 & 15.5 \\
\hline Disagree & 3 & 5.2 \\
\hline Strongly Disagree & 1 & 1.5 \\
\hline Strongly Agree & 30 & 51.7 \\
\hline Agree & 14 & 24.1 \\
\hline Undecided & 10 & 17.5 \\
\hline Disagree & 2 & 3.4 \\
\hline Strongly Disagree & 2 & 3.4 \\
\hline
\end{tabular}




\section{To pay for taxes affect long term investment}

To pay for community services affect profitability ratio

To pay community services affect increase in sale volume

To pay community services affect long term investment

\begin{tabular}{lrr} 
Strongly Agree & 29 & 50.0 \\
Agree & 14 & 24.1 \\
Undecided & 9 & 15.5 \\
Disagree & 3 & 5.2 \\
Strongly Disagree & 3 & 5.2 \\
Strongly Agree & 31 & 53.4 \\
Agree & 14 & 24.1 \\
Undecided & 1 & 1.7 \\
Disagree & 9 & 15.5 \\
Strongly Disagree & 3 & 5.1 \\
Strongly Agree & 30 & 51.7 \\
Agree & 15 & 25.9 \\
Undecided & 1 & 1.7 \\
Disagree & 4 & 6.9 \\
Strongly Disagree & 2 & 3.4 \\
Strongly Agree & 28 & 48.3 \\
Agree & 14 & 24.1 \\
Undecided & 8 & 13.8 \\
Disagree & 5 & 8.6 \\
Strongly Disagree & 3 & 5.2 \\
\hline
\end{tabular}

Source: Primary Data, 2019

The Results in table 3. Indicates that $26(44.8 \%)$ of Respondents strongly agreed that buying airtime with MOMO service affect an increase in Sales volume of MTN Rwanda, 27 (46.6\%) of Respondents strongly agreed that buying airtime with MOMO service positively affect long - Term Investment of MTN Rwanda, 27 (46.6\%) of Respondents strongly agreed that buying airtime with MOMO service highly affect profitability Ratio of MTN Rwanda, 23 (39.7\%) of Respondents strongly agreed that paying for electricity with MOMO service affect an increase in sales, $26(44.8 \%)$ of Respondents strongly

highly affects profitability ration of MTN Rwanda, 29 (50.0\%) of Respondents strongly agreed with agreed that paying for electricity with MOMO service highly affect profitability Ratio, 26 (44.8\%) of Respondents strongly agreed that paying TV with MOMO service affect an increase of sales volume of MTN Rwanda. The same Table 4.7 indicates that $27(46.6 \%)$ of Respondents strongly agreed that paying TV with MOMO service positively affect long term investment of MTN Rwanda, $32(55.2 \%)$ of Respondents strongly agreed that postpaid bill payment the above mentioned statement, 30 (51.7\%) of Respondents strongly agreed that postpaid bill payment affecting positively long term investment of MTN Rwanda, 29 (50.0\%) of Respondents strongly agreed with the above mentioned statement, 28 (48.3\%) of Respondents strongly agreed that paying school fees with MOMO service highly affect profitability Ratio of MTN Rwanda, 28 (48.3\%) of Respondents strongly agreed with the above mentioned statement, $29(50.0 \%)$ of Respondents Agreed that paying school fees with MOMO services positively affect long term investment. The same table 4.7 indicates that $30(51.7 \%)$ of Respondents strongly agreed that paying school fees with MOMO service affect an increase of sales volume, 31 (53.4\%) of Respondents strongly agreed that paying for tax with MOMO service highly affect profitability ratio of MTN Rwanda, 30 $(51.7 \%)$ of Respondents strongly agreed that paying for tax with MOMO service affect an increase of sales volume, $29(50.0 \%)$ of Respondents strongly agreed that paying for community service with MOMO service highly affect profitability Ratio of MTN Rwanda, 31 (53.4\%) of Respondents strongly agreed that paying for community service with MOMO service affect an increase of sales volume of MTN Rwanda. Hence, this implies that mobile money payment affects financial performance of MTN Rwanda.

\subsubsection{Mobile banking services on financial performance of MTN Rwanda}

In this sub-section, the data presented, analyzed and interpreted are related to impact of mobile banking service on financial performance of MTN Rwanda basing on the collected data through interview and questionnaire. 
Table 4: Perceptions of respondents about mobile banking services on financial performance of MTN Rwanda

\begin{tabular}{|c|c|c|c|}
\hline & & $\begin{array}{l}\text { Frequency } \\
(n=58)\end{array}$ & Percent \\
\hline \multirow{6}{*}{$\begin{array}{l}\text { To deposit and withdraw money on bank account with } \\
\text { MOMO affect profitability ratio }\end{array}$} & Strongly Agree & 32 & 55.2 \\
\hline & Agree & 14 & 24.1 \\
\hline & Undecided & 8 & 13.8 \\
\hline & Disagree & 2 & 3.4 \\
\hline & Strongly Disagree & 2 & 3.4 \\
\hline & Strongly Agree & 32 & 55.2 \\
\hline \multirow{5}{*}{$\begin{array}{l}\text { To deposit and withdraw money on bank account with } \\
\text { MOMO affect increase in sales volume }\end{array}$} & Agree & 14 & 24.1 \\
\hline & Undecided & 9 & 15.5 \\
\hline & Disagree & 2 & 3.4 \\
\hline & Strongly Disagree & 1 & 1.7 \\
\hline & Strongly Agree & 31 & 53.4 \\
\hline \multirow{5}{*}{$\begin{array}{l}\text { To deposit and withdraw money on bank account with } \\
\text { MOMO affect service long term investment }\end{array}$} & Agree & 15 & 25.9 \\
\hline & Undecided & 8 & 13.8 \\
\hline & Disagree & 3 & 5.2 \\
\hline & Strongly Disagree & 1 & 1.7 \\
\hline & Strongly Agree & 31 & 53.4 \\
\hline \multirow{5}{*}{$\begin{array}{l}\text { To check account balance with MOMO service affect } \\
\text { profitability ratio }\end{array}$} & Agree & 15 & 25.9 \\
\hline & Undecided & 8 & 13.8 \\
\hline & Disagree & 1 & 1.7 \\
\hline & Strongly Disagree & 3 & 5.2 \\
\hline & Strongly Agree & 31 & 53.4 \\
\hline \multirow{5}{*}{$\begin{array}{l}\text { To check account balance with MOMO service affect } \\
\text { increase in sales volume }\end{array}$} & Agree & 13 & 22.4 \\
\hline & Undecided & 9 & 15.5 \\
\hline & Disagree & 4 & 6.9 \\
\hline & Strongly Disagree & 1 & 1.7 \\
\hline & Strongly Agree & 29 & 50.0 \\
\hline \multirow{4}{*}{$\begin{array}{l}\text { To check account balance with MOMO service affect } \\
\text { long term investment }\end{array}$} & Agree & 14 & 24.1 \\
\hline & Undecided & 8 & 13.8 \\
\hline & Disagree & 3 & 5.2 \\
\hline & Strongly Disagree & 4 & 6.9 \\
\hline
\end{tabular}

Source: Primary Data, 2019

The Results in Table 4. Indicates that $32(55.2 \%)$ of Respondents strongly agreed that depositing and withdrawing money on bank account with MOMO service highly affect profitability Ratio, $32(55.2 \%)$ of Respondents strongly agreed that depositing and withdrawing money on bank account with MOMO service affect long term investment of MTN Rwanda, 31 (53.4\%) of Respondents strongly agreed that depositing and withdrawing money on bank account with MOMO service affect long term investment of MTN Rwanda, 31 (53.4\%) of Respondents strongly agreed that depositing money on bank account with MOMO service affect increase of sales volume of MTN Rwanda, 31 (53.4\%) of Respondents strongly agreed that MTN Rwanda MOMO Services that are used to Send Money Outside the Country affects Profitability of MTN Rwanda, 29 (50.0\%) of Respondents strongly agreed checking balance on bank account with MOMO service affect an increase of sales volume of MTN Rwanda. Hence, this implies that checking balance on bank account with MOMO service affect an increase of sales volume of MTN Rwanda.

3.1.5 Financial key performance indicators of MTN Rwanda.

Financial key performance indicators were added for evaluating the dependent variable and also to achieve the second objective of the study. 


\begin{tabular}{|c|c|c|}
\hline & $\begin{array}{r}\text { Frequency } \\
(n=58)\end{array}$ & Percent \\
\hline \multicolumn{3}{|l|}{ Improved Sales Volume } \\
\hline Strongly agree & 6 & 10.3 \\
\hline Agree & 8 & 13.8 \\
\hline Undecided & 30 & 51.7 \\
\hline Disagree & 7 & 12.1 \\
\hline Strongly disagree & 7 & 12.1 \\
\hline Total & 58 & 100.0 \\
\hline \multicolumn{3}{|l|}{ Profitability ratio } \\
\hline Strongly agree & 5 & 8.6 \\
\hline Agree & 9 & 15.5 \\
\hline Undecided & 29 & 50.0 \\
\hline Disagree & 8 & 13.8 \\
\hline Strongly disagree & 7 & 12.1 \\
\hline Total & 58 & 100.0 \\
\hline \multicolumn{3}{|l|}{ Long Term Investment } \\
\hline Strongly agree & 5 & 8.6 \\
\hline Agree & 7 & 12.1 \\
\hline Undecided & 33 & 56.9 \\
\hline Disagree & 8 & 13.8 \\
\hline Strongly disagree & 5 & 8.6 \\
\hline Total & 58 & 100.0 \\
\hline
\end{tabular}

\section{Source: Primary Data, 2019}

Table 5 shows that 6 (10.3) of Respondents Strongly agreed that e-payment system affect an increase of sales volume of MTN Rwanda, 5 (8.6) of Respondents strongly agreed that e-payment system highly affect profitability ratio of MTN Rwanda,5 (8.6) of Respondents strongly agreed that e-payment system positively affect Long term investment of MTN Rwanda. In addition, 8 (13.8) of Respondents agreed that e-payment system affect an increase of sales volume of MTN Rwanda, 9 (15.5) of Respondents agreed that e-payment system highly affect profitability ratio of MTN Rwanda, 7 (12.1) of Respondents agreed that e-payment system positively affect Long term investment of MTN Rwanda. Thus, 30 (51.7) of Respondents Undecided that e-payment system affect an increase of sales volume of MTN Rwanda, 29 (50.0) of Respondents Undecided that e-payment system highly affect profitability ratio of MTN Rwanda, 33 (56.9) of Respondents Undecided that e-payment system positively affect Long term investment of MTN Rwanda. Hence, 7(12.1) of Respondents Disagreed that e-payment system affect an increase of sales volume of MTN Rwanda, 8 (13.8) of Respondents Disagreed that e-payment system highly affect profitability ratio of MTN Rwanda, 8 (13.8) of Respondents Disagreed that e-payment system positively affect Long term investment of MTN Rwanda. Therefore 7(12.1) of Respondents Strongly disagreed that epayment system affect an increase of sales volume of MTN Rwanda, 7 (12.1) of Respondents Strongly disagreed that e-payment system highly affect profitability ratio of MTN Rwanda, 5 (8.6) of Respondents Strongly disagreed that e-payment system positively affect Long term investment of MTN Rwanda.

\subsubsection{Relationship between e-payment system and financial performance.}

This section concentrates on the relationship between the two variables: e-payment system and financial performance. 
Table 6:Correlation between e-payment system and financial performance of MTN Rwanda.

\begin{tabular}{|c|c|c|c|c|c|c|c|}
\hline & & $\begin{array}{l}\text { Money } \\
\text { Transfer } \\
\text { Services }\end{array}$ & $\begin{array}{l}\text { Payment } \\
\text { Services }\end{array}$ & $\begin{array}{l}\text { Mobile } \\
\text { Banking } \\
\text { Services }\end{array}$ & $\begin{array}{l}\text { Improved } \\
\text { Sales } \\
\text { Volume }\end{array}$ & Profitability & $\begin{array}{l}\text { Long Term } \\
\text { Investment }\end{array}$ \\
\hline Money & Pearson & 1 & $.785^{* *}$ & $.973^{* *}$ & $.844^{* *}$ & $.821^{* * *}$ & $.774^{* *}$ \\
\hline Transfer & Correlation & & & & & & \\
\hline \multirow[t]{2}{*}{ Services } & Sig. (2-tailed) & & .000 & .000 & .000 & .000 & .000 \\
\hline & $\mathrm{N}$ & 58 & 58 & 58 & 58 & 58 & 58 \\
\hline Payment & Pearson & $.785^{* *}$ & 1 & $.781^{* *}$ & $.933^{* *}$ & $.972^{* *}$ & $.986^{* *}$ \\
\hline \multirow[t]{3}{*}{ Services } & Correlation & & & & & & \\
\hline & Sig. (2-tailed) & .000 & & .000 & .000 & .000 & .000 \\
\hline & $\mathrm{N}$ & 58 & 58 & 58 & 58 & 58 & 58 \\
\hline Mobile & Pearson & $.973^{* *}$ & $.781^{* *}$ & 1 & $.866^{* *}$ & $.845^{* *}$ & $.799^{* *}$ \\
\hline Banking & Correlation & & & & & & \\
\hline \multirow[t]{2}{*}{ Services } & Sig. (2-tailed) & .000 & .000 & & .000 & .000 & .000 \\
\hline & $\mathrm{N}$ & 58 & 58 & 58 & 58 & 58 & 58 \\
\hline Improved & Pearson & $.844^{* *}$ & $.933^{* *}$ & $.866^{* *}$ & 1 & $.987^{* *}$ & $.946^{* *}$ \\
\hline Sales & Correlation & & & & & & \\
\hline \multirow[t]{2}{*}{ Volume } & Sig. (2-tailed) & .000 & .000 & .000 & & .000 & .000 \\
\hline & $\mathrm{N}$ & 58 & 58 & 58 & 58 & 58 & 58 \\
\hline \multirow[t]{3}{*}{ Profitability } & $\begin{array}{l}\text { Pearson } \\
\text { Correlation }\end{array}$ & $.821^{* *}$ & $.972^{* *}$ & $.845^{* *}$ & $.987^{* *}$ & 1 & $.986^{* *}$ \\
\hline & Sig. (2-tailed) & .000 & .000 & .000 & .000 & & .000 \\
\hline & $\mathrm{N}$ & 58 & 58 & 58 & 58 & 58 & 58 \\
\hline Long Term & Pearson & $.774^{* *}$ & $.986^{* *}$ & $.799^{* *}$ & $.946^{* *}$ & $.986^{* *}$ & 1 \\
\hline \multirow[t]{3}{*}{ Investment } & Correlation & & & & & & \\
\hline & Sig. (2-tailed) & .000 & .000 & .000 & .000 & .000 & \\
\hline & $\mathrm{N}$ & 58 & 58 & 58 & 58 & 58 & 58 \\
\hline
\end{tabular}

Source: Primary Data, 2019

The findings in Table 6. proves that there is a positive correlation between money transfer services and long term investment ( $\mathrm{p}=.774$ and $\mathrm{sig}=.000)$; between payment and profitability $(\mathrm{p}=.972$ and $\mathrm{sig}=.000)$; between mobile banking services and improved sales volume $(\mathrm{p}=.866 \mathrm{and}$ sig $=.000)$; between money transfer services and payment services $(\mathrm{p}=.785$ and $\mathrm{sig}=.000)$; between payment service and mobile banking services $(\mathrm{p}=.781$ and sig= .000$)$; long term investment and profitability $(\mathrm{p}=.986$ and $\mathrm{sig}=.000)$; to mention but few. Hence, the results indicate that e-payment systems have a positive and significant relationship with financial performance of MTN Rwanda MOMO services.

\subsection{Relationship between e-payment and key performance of financial performance of MTN Rwanda.}

3.2.1 E-payment systems and improved sales volume

This section shows that e-payment have a relationship with improved sales volume.

Table 7: Model Summary of e-payment systems and improved sales volume

\begin{tabular}{llrrr}
\hline Model & R & R Square & Adjusted R Square & Std. Error of the Estimate \\
\hline 1 & $.961^{\text {a }}$ & .923 & .919 & \\
a. Predictors: (Constant), Mobile Banking Services, Payment Services, Money Transfer Services & .23072
\end{tabular}

\section{Source: Primary Data, 2019}

The results in Table 7. revealed that the R coefficient .961 shows that the e-payment systems have a positive relationship with improved sales volume. The coefficient of determination $.923 \mathrm{R}$ square also shows that epayment systems explains $92.3 \%$ of the variability in improved sales volume. Thus, basing on the findings predictors measures such as constant, money transfer service, payment services and mobile banking services affect the progress of improved sales volume by $92.3 \%$ in MTN Rwanda MOMO services.

3.2.2 E-payment systems and profitability ratio

This section shows that e-payment have a relationship with profitability ratio. 
Table 8: Model Summary of e-payment systems and profitability ratio

\begin{tabular}{lllll}
\hline Model & R & R Square & Adjusted R Square & Std. Error of the Estimate \\
\hline 1 & $.986^{\mathrm{a}}$ & .971 & .970 & .13627 \\
a. Predictors: (Constant), Mobile Banking Services, Payment Services, Money Transfer Services
\end{tabular}

\section{Source: Primary Data, 2019}

The results in Table 8 . revealed that the $\mathrm{R}$ coefficient .986 shows that the e-payment systems have a positive relationship with profitability. The coefficient of determination $.971 \mathrm{R}$ square also shows that e-payment systems explains $97.1 \%$ of the variability in profitability. Thus, basing on the findings predictors measures such as constant, money transfer service, payment services and mobile banking services affect the progress of profitability by $97.1 \%$ in MTN Rwanda MOMO services.

\subsubsection{E-payment systems and long term investment}

This section shows that e-payment have a relationship with long term investment. Table 9: Model Summary of e-payment systems and long term investment

\begin{tabular}{lllll}
\hline Model & $\mathrm{R}$ & $\mathrm{R}$ Square & Adjusted R Square & Std. Error of the Estimate \\
\hline 1 & $.993^{\mathrm{a}}$ & .986 & .985 & .09437 \\
\hline
\end{tabular}

a. Predictors: (Constant), Mobile Banking Services, Payment Services, Money Transfer Services

Source: Primary Data, 2019

The results in Table 9. revealed that the R coefficient .993 shows that the e-payment systems have a positive relationship with long term investment. The coefficient of determination $.986 \mathrm{R}$ square also shows that e-payment systems explains $98.6 \%$ of the variability in long term investment. Thus, basing on the findings predictors measures such as constant, money transfer service, payment services and mobile banking services affect the progress of long term investment by $98.6 \%$ in MTN Rwanda MOMO services.

\section{Conclusion and Recommendations}

\subsection{Conclusion}

The findings on how e-payment system influence the financial performance of MTN Rwanda shows that a high percentage of MOMO service consumers influence e-payment system such as mobile money transfer, mobile banking and e-payment to improve financial performance of MTN Rwanda whereby it is demonstrated through achieved profitability ratio, long - term investment and improved sales volume. Therefore, to increase the profit of a business, business owners need to use e- payment systems as the same as the telecom companies also earn more money in e-payment. In conclusion all predictors of e-payment system such as mobile money transfer service, e-payment services and mobile banking services influences financial performance by improved sales volume, profitability ratio and long term investment. Hence, there is a positive correlation between money transfer services and long term investment $(\mathrm{p}=.774$ and $\mathrm{sig}=.000)$; between payment and profitability $(\mathrm{p}=.972$ and $\mathrm{sig}=.000)$; between mobile banking services and improved sales volume $(\mathrm{p}=.866$ and sig=.000); between money transfer services and payment services $(\mathrm{p}=.785$ and sig=.000); between payment service and mobile banking services $(\mathrm{p}=.781$ and $\mathrm{sig}=.000)$; long term investment and profitability $(\mathrm{p}=.986$ and $\mathrm{sig}=.000)$.

\subsection{Recommendations}

The findings of the study show that there is a relationship between e-payment systems and financial performance of MTN Rwanda as same as to the consumer. Hence, business owners and companies should adopt use of the epayment systems in order to improve their financial performance which can at large affect the economic development of the country and easy delivery of services.

\section{References}

Nzaro, R., \& Magidi, N. (2014). Assessing the Role of Electronic Payment Systems in Financial Institutions. A Case of a Savings Bank in Zimbabwe. Type: Double Blind Peer Reviewed International Research Journal Publisher: Global Journals Inc, 14(2).

Oloko, M. (n.d.). EFFECT OF TELECOM MONEY TRANSFER SERVICES ON FINANCIAL PERFORMANCE OF. 55-64.

Ul, B., F., R., Mehraj, A., Ahmad, A., \& Assad, S. (2017). A Compendious Study of Online Payment Systems: Past Developments, Present Impact, and Future Considerations. International Journal of Advanced Computer Science and Applications, 8(5), 256-271. https://doi.org/10.14569/ijacsa.2017.080532

Abor, (2004) 'Technological Innovations and Banking in Ghana: An Evaluation of Customers' Perceptions' African journal online.

Abrazhevich (2004) 'Electronic payment systems: a user-centered perspective and interaction design'.

Ali, R. (2010). E-Government Adoption in Developing Countries:

Al-Jabri,(2012) 'Mobile banking adoption: Application of diffusion of innovation theory'. Journal of electronic 
commerce research.

Anuradi, Tygi and Raddi, (2009). 'The impact of mobile payments on the success and growth of micro-business'. Journal of language, technology and entrepreneurship in Africa.

Arunga and Kahora (2007) 'The cell phone revolution in Kenya'. International press.

Bank for International Settlements, (2000) 'BIS Annual Economic Report'.

Barnes \& Corbit, (2003). Determinants of Mobile Banking Adoption in the Ghanaian Banking Industry.

Burhan UI Islam Khan, (2017) 'A survey on E-payment systems: Elements, Adoption, Architecture, challenges and security concepts.' Indian journal of science and technology.

Bill Maurer (2012) Mobile money: Communication, Consumption and change in the payments space. The journal of development studies.

David Asamoah (2019) Examining the effect of mobile money transfer (MMT) capabilities on business growth and development impact. Information Technology for development.

Evangelos,(2004). The software infrastructure for the development and validation of the Greek WordNet, Harvard Business School.

GSMA (2014). Mobile Money for the Unbanked Mobile money profitability: A digital ecosystem to drive healthy margins.

Hughes and Lonie (2007). M-PESA: Mobile Money for the "Unbanked"International Journal of electronic commerce.

Kalakota\&Whiston (1997) 'Electronic commerce' Kalakota, University of Rochester. Whinston, University of Texas.

Kanyi and Maharaj (2011). 'Factors influencing successful use of mobile technologies to facilitate e-commerce in small enterprises'. The African journal of information systems.

Keck,(2010) 'Benefits and risks of electronic payment system'. International journal of E business Research.

Kim et al,(2010) 'the determinants of electronic payment systems from consumers' perspective'. Economic Research.

Kothari, (2004). Research Methodology: Methods and Techniques.

Mallat (2007), Exploring Consumer Adoption of Mobile Payments-A Qualitative Study. Manheim and Rich (1995),

Roy \& Sinha, (2014) 'Adoption of e-payment systems'. International conference on E-commerce.

Singh,(2017). Evaluating the Performance of Mobile Telecom Operators in India. InternationalJournal of Simulation: Systems, Science \& Technology.

Yahid,Shahbahrami, \& Nobakht, (2013) 'Providing security for e-wallet using e-cheque'. International conference on e-commerce. 